\title{
FACTORS ASSOCIATED WITH CARDIAC ENLARGEMENT IN MYXEDDEMA
}

\author{
BY \\ C. P. ABER*, AND G. S. THOMPSON \\ Liverpool Royal Infirmary, and the Royal Southern Hospital, Liverpool
}

Received October 9, 1962

Involvement of the heart in hypothyroidism (myxœdema heart disease) was first recorded by Zondek in 1918. Since then attention has been focused on the histological characteristics of the cardiac lesion and the clinical manifestations of myxœdema heart disease (Fahr, 1925; Campbell and Suzman, 1934; Means, 1937; Fournier, 1942; Bustamante et al., 1955; Hamilton and Greenwood, 1957). Myocardial damage (Hallock, 1933; Means, 1937; Ellis et al., 1952; Hamilton and Greenwood, 1957), pericardial effusion (Freeman, 1934; Marzullo and Franco, 1939; Boivin, 1945; Schnitzer and Gutmann, 1946; Kern et al., 1949), and premature coronary artery disease (Fishberg, 1924; Fahr, 1925) have all been shown to occur, but the incidence of these various lesions is still uncertain. This, no doubt, has in part been due to the relatively small number of patients studied in previous investigations.

Radiological enlargement of the heart has also been said to be common in myxœdema, due either to myocardial damage (cardiomyopathy) or to the presence of a pericardial effusion or as a consequence of both of these lesions (Hallock, 1933; Freeman, 1934; Means, 1937, Scherf and Boyd, 1939; Schnitzer and Gutmann, 1946; Kern et al., 1949; Hamilton and Greenwood, 1957). Similarly, electrocardiographic evidence of myxœdema heart disease is reported as occurring in 70 to 80 per cent of patients with established myxœdema (Lerman, Clark, and Means, 1933; Bellet and McMillan, 1945; Hamilton and Greenwood, 1957).

Such observations have led to the belief that radiological cardiac enlargement is an almost invariable accompaniment of obvious cardiographic evidence of myxœdema heart disease, whether or not there have been previous symptoms of cardiac embarrassment. This alleged relation, however, has never been proven. The present investigation was therefore designed to study some of the factors influencing heart size and the electrocardiogram in myxœdema.

\section{SUBJECTS AND METHODS}

The clinical records of 53 myxœdematous patients (6 men and 47 women) were collected from the medical units of two Liverpool hospitals (Liverpool Royal Infirmary and the Royal Southern Hospital). The majority of these patients had undoubted clinical myxœdema, but in most of them, and always when there was any doubt, radioactive iodine studies were performed to establish the diagnosis.

Electrocardiogram. Each patient was placed into one of two groups (A and B) according to the cardiographic pattern.

Group A. A conventional 12-lead electrocardiogram showed evidence of myxœdema heart disease in that three or four of the following features were present:-(i) sinus bradycardia, (ii) generalized low voltage, (iii) prolongation of the $P-R$ interval, and (iv) generalized flattening or inversion of the $T$ waves.

Group $B$. The electrocardiogram was normal, or it lacked the evidence of myxœdema heart disease as judged by the above criteria, or there was evidence of left ventricular hypertrophy or coronary artery disease.

* Now at Cardiovascular Research Institute, San Francisco Medical Center, University of California. 
TABLE I

Relation of Heart Size to Electrocardiographic Pattern in 53 Patients with Myxcedema

\begin{tabular}{|c|c|c|c|c|c|}
\hline & & & \multicolumn{3}{|c|}{ Heart size } \\
\hline & & & $\begin{array}{c}\text { Normal } \\
(\mathrm{C} / \mathrm{T}<50 \%)\end{array}$ & $\begin{array}{l}\text { Moderate enlargement } \\
\text { (C/T } 50 \%-65 \%)\end{array}$ & $\begin{array}{l}\text { Great enlargement } \\
(\mathrm{C} / \mathrm{T}>65 \%)\end{array}$ \\
\hline $\begin{array}{c}\text { Group A (27 patients) } \\
\text { Group B (26 patients) } \\
\text { Total } \quad . . \quad \ldots\end{array}$ & $\begin{array}{l}. \\
\cdots \\
.\end{array}$ & $\begin{array}{l}\cdots \\
\cdots \\
\cdots\end{array}$ & $\begin{array}{r}14(52 \%) \\
9(35 \%) \\
23(43 \%)\end{array}$ & $\begin{array}{l}8(29 \cdot 5 \%) \\
12(46 \%) \\
20(38 \%)\end{array}$ & $\begin{array}{l}5(18 \cdot 5 \%) \\
5(19 \%) \\
10(19 \%)\end{array}$ \\
\hline
\end{tabular}

Heart Size. The cardio-thoracic $(\mathrm{C} / \mathrm{T})$ ratio was used as an index of heart size. These measurements were made from conventional postero-anterior chest radiograms before the start of replacement hormone therapy. On the basis of this ratio each patient was considered to have either (i) a normal-sized heart, when the $C / T$ ratio was less than 50 per cent, (ii) moderate enlargement, when the $C / T$ ratio was between 50 and 65 per cent, or (iii) great enlargement of the heart when the $C / T$ ratio was greater than 65 per cent.

In addition to the above observations the blood pressure of each patient was recorded, and when present a history of angina of effort was also noted.

\section{RESULTS}

Electrocardiogram. Typical myxœdematous records were observed in 27 instances $(51 \%)$ (Group A). Of the remaining 26 patients (Group B), $5(9 \%)$ had normal records, $11(21 \%)$ had minor abnormalities (less than three of the typical features of myxœdema heart disease), $6(11 \%)$ had undoubted evidence of coronary artery disease or myocardial infarction, $2(4 \%)$ had changes of left ventricular hypertrophy, and $2(4 \%)$ had a left bundle-branch block pattern.

Heart Size. Over half the patients $(52 \%)$ in Group A had normal-sized hearts, whereas cardiac enlargement was observed in 81 per cent of the patients with abnormal electrocardiograms in Group B. Considerable cardiac enlargement, however, was relatively uncommon in both groups (Table I), and the five patients with normal electrocardiograms had normal-sized hearts.

Factors Associated with Cardiac Enlargement in Myxadema. In Group A the 13 patients with enlarged hearts were, in the main, considerably older and had appreciably higher systemic blood pressures than those patients in this group with normal-sized hearts: only $5(18.5 \%)$ of the patients with enlarged hearts were less than 55 years of age, and only $4(15 \%)$ had either systolic blood pressures of $155 \mathrm{~mm}$. $\mathrm{Hg}$ or less, or diastolic blood pressures lower than $95 \mathrm{~mm}$. Hg. Similarly, a history of angina of effort was more frequent in those patients with cardiac enlargement (Table II).

In Group B moderate cardiac enlargement was found in $6(55 \%)$ of the 11 patients with minor

TABLE II

Relation of Age, Blood Pressure, and Angina of Effort to Heart Size in Group A

\begin{tabular}{|c|c|c|c|c|c|}
\hline Heart size & $\begin{array}{c}\text { Mean age } \\
\text { (years) }\end{array}$ & $\begin{array}{l}\text { Mean systemic } \\
\text { blood pressure } \\
\quad(\mathrm{mm} . \mathrm{Hg})\end{array}$ & $\begin{array}{c}\text { Systolic } \\
\text { pressure } \\
<155 \mathrm{~mm} . \mathrm{Hg} \mathrm{( \% )}\end{array}$ & $\begin{array}{c}\text { Diastolic } \\
\text { pressure } \\
<95 \mathrm{~mm} . \mathrm{Hg}(\%)\end{array}$ & $\begin{array}{l}\text { Incidence } \\
\text { of angina } \\
\text { of effort }(\%)\end{array}$ \\
\hline $\begin{array}{l}\text { Normal } \\
\text { (14 patients) }\end{array}$ & $\begin{array}{c}45 \\
\text { (range 27-65) }\end{array}$ & $\begin{array}{c}125 / 82 \\
\text { (range } 90 / 65-\end{array}$ & 86 & 86 & 7 \\
\hline $\begin{array}{l}\text { Enlarged hearts } \\
\text { (13 patients) }\end{array}$ & $\begin{array}{c}59 \\
\text { (range } 34-76 \text { ) }\end{array}$ & $\begin{array}{c}167 / 103 \\
\text { (range } 105 / 80- \\
200 / 130\end{array}$ & 15 & 15 & 43 \\
\hline
\end{tabular}


electrocardiographic abnormalities. In the remaining 10 patients of this group with abnormal electrocardiograms, however, cardiac enlargement was invariable and often marked (Table II). The patients with minor cardiographic abnormalities were usually appreciably younger and had considerably lower blood pressures than those with cardiographic evidence of left ventricular hypertrophy, coronary artery disease or left bundle-branch block. Similarly, a history of angina of effort was only found in the latter ten patients in Group B (Table III).

TABLE III

Relation of Electrocardiographic Patterns to Heart Size, Age, Blood Pressure, and Incidence of Angina of EFFORT IN GROUP B

\begin{tabular}{|c|c|c|c|c|c|c|c|}
\hline \multirow[b]{2}{*}{ Electrocardiogram } & \multicolumn{2}{|c|}{ Heart size } & \multirow{2}{*}{$\begin{array}{c}\text { Mean } \\
\text { age } \\
\text { (years) }\end{array}$} & \multirow{2}{*}{$\begin{array}{l}\text { Mean systemic } \\
\text { blood pressure } \\
(\mathrm{mm} . \mathrm{Hg})\end{array}$} & \multirow{2}{*}{$\begin{array}{c}\text { Systolic } \\
\text { pressure } \\
<155 \mathrm{~mm} . \mathrm{Hg} \\
(\%)\end{array}$} & \multirow{2}{*}{$\begin{array}{c}\text { Diastolic } \\
\text { pressure } \\
<95 \mathrm{~mm} . \mathrm{Hg} \\
(\%)\end{array}$} & \multirow{2}{*}{$\begin{array}{c}\text { Incidence } \\
\text { of angina } \\
\text { of effort } \\
(\%)\end{array}$} \\
\hline & $\begin{array}{c}\text { Normal } \\
(\%)\end{array}$ & $\underset{(\%)}{\text { Enlarged }}$ & & & & & \\
\hline $\begin{array}{l}\text { Normal } \\
\text { (5 patients) }\end{array}$ & 100 & 0 & $\begin{array}{c}50 \\
\text { (range } \\
40-60\end{array}$ & $\begin{array}{c}146 / 88 \\
\text { (range 120/80- } \\
160 / 100 \text { ) }\end{array}$ & 60 & 80 & 0 \\
\hline $\begin{array}{l}\text { Minor abnormalities } \\
\text { (11 patients) }\end{array}$ & 45 & 55 & $\begin{array}{c}51 \\
\text { (range } \\
33-61)\end{array}$ & $\begin{array}{l}146 / 84 \\
\text { (range } 105 / 70- \\
230 / 130)\end{array}$ & 73 & 64 & 0 \\
\hline $\left.\begin{array}{l}\text { Coronary artery } \\
\text { disease } \\
\text { L.V. hypertrophy } \\
\text { L.B.B. block } \\
\text { (10 patients) }\end{array}\right\}$ & 0 & 100 & $\begin{array}{c}63 \\
\text { (range } \\
46-74)\end{array}$ & $\begin{array}{c}174 / 100 \\
\text { (range } 140 / 90 \\
240 / 130\end{array}$ & 30 & 30 & 70 \\
\hline
\end{tabular}

\section{Discussion}

The present findings are of interest for several reasons. First, it has been shown that typical electrocardiographic evidence of myxœdema heart disease can be observed in the absence of obvious radiological abnormalities of the heart. However, it is still not clear whether under such circumstances the lesion is myocardial or pericardial in nature. It is likely that persistent cardiographic changes of this type are due to myocardial damage, since on experimental evidence in normal animals (Katz, Feil and Scott, 1929) such changes only occur with an appreciable pericardial effusion which would be expected to cause an increase in the radiological heart size.

Secondly, it appears that advancing age, systemic arterial hypertension, and coronary heart disease are in part responsible for the increase in heart size in myxœdema. This is not surprising since older patients may well have been myxœdematous for a longer time than younger patients, although this point is not easy to establish owing to the obvious difficulty in determining when the disease started. Furthermore, while both hypertension and coronary artery disease are wellrecognized features of myxœdema, both also occur with increasing frequency with advancing years.

In conclusion, it appears that patients with established myxœdema, who have also typical electrocardiographic evidence of myxœdema heart disease, often have normal-sized hearts. On the other hand, radiological enlargement of the heart in myxœdema is usually associated with an abnormal electrocardiogram. This latter group of patients, however, are usually over 55 years of age and often have hypertension or coronary artery disease.

\section{SUMMARY}

A study has been made of the electrocardiographic changes and the radiological size of the heart in 53 patients with myxœdema.

Typical cardiographic changes of myxœdema heart disease were observed in $27(51 \%)$ patients. Of the remaining 26 patients, 11 had minor cardiographic abnormalities, 6 had evidence of coronary 
artery disease or myocardial infarction, 2 had left ventricular hypertrophy, and 2 a left bundlebranch block pattern: 5 patients $(9 \%)$ had normal records.

Cardiac enlargement was found in 29 patients $(55 \%)$, most of whom were older and had appreciably higher systemic blood pressures than those patients with normal-sized hearts. Six of the seven with angina of effort had cardiac enlargement. Fourteen patients $(26 \%)$ had typical cardiographic changes of myxœdema heart disease with normal-sized hearts.

The finding of a normal-sized heart in myxœdema probably implies lack of associated hypertension or coronary artery disease, despite the presence of an electrocardiogram typical of myxœdema heart disease.

We wish to thank the physicians of the Liverpool Royal Infirmary and the Royal Southern Hospital, Liverpool, for allowing us access to their cases for this study.

\section{REFERENCES}

Bellet, S., and McMillan, T. M. (1945). In The Diagnosis and Treatment of Cardiovascular Disease, 3rd ed., edited by W. D. Stroud. Davis, Philadelphia.

Boivin, J. M. (1945). Histoire d'un épanchement péricardique récidivant asséché par l'extrait thyroïdien. Arch. Mal. Caur, 38, 289.

Bustamante, R., Perez Stable, E., Casas Rodriguez, R., and Mateo De Acosta, O. (1955). Corazón mixedematoso: estudio clinico de 34 casos. Rev. cuba. Cardiol., 16, 405.

Campbell, M., and Suzman, S. S. (1934). The heart in myxœdema. Guy's Hosp. Rep., 84, 281.

Ellis, L. B., Mebane, J. G., Maresh, G., Hultgren, H. N., and Bloomfield, R. A. (1952). The effect of myxedema on the cardiovascular system. Amer. Heart J., 43, 341.

Fahr, G. (1925). Myxedema heart. J. Amer. med. Ass., 84, 345.

Fishberg, A. M. (1924). Arteriosclerosis in thyroid deficiency. J. Amer. med. Ass., $82,463$.

Fournier, J. C. M. (1942). The circulatory apparatus in myxedema. Proc. Mayo Clin., 17, 212.

Freeman, E. B. (1934). Chronic pericardial effusion in myxedema: report of case. Ann. intern. Med., 7, 1070.

Hallock, P. (1933). The heart in myxedema, with a report of two cases. Amer. Heart J., 9, 196.

Hamilton, J. D., and Greenwood, W. F. (1957). Myxedema heart disease. Circulation, 15, 442.

Katz, L. N., Feil, H. S., and Scott, R. W. (1929). The electrocardiogram in pericardial effusion. II. Experimental. Amer. Heart J., 5, 77.

Kern, R. A., Soloff, L. A., Snape, W. J., and Bello, C. T. (1949). Pericardial effusion: A constant, early and major factor in the cardiac syndrome of hypothyroidism (myxedema heart). Amer. J. med. Sci., 217, 609.

Lerman, J., Clark, R. J., and Means, J. H. (1933). Heart in myxedema; electrocardiograms and roentgen-ray measurements before and after therapy. Ann. intern. Med., 6, 1251.

Marzullo, E. R., and Franco, S. (1939). Myxedema with multiple serous effusions and cardiac involvement (myxedema heart); case report. Amer. Heart J., 17, 368.

Means, J. H. (1937). The Thyroid and Its Diseases. Lippincott, Philadelphia.

Scherf, D., and Boyd, L. J. (1939). Cardiovascular Diseases. Mosby, St. Louis.

Schnitzer, R., and Gutmann, D. (1946). Myxœdema with pericardial effusion. Brit. Heart J., 8, 25.

Zondek, H. (1918). Das Myxödemherz. Münch. med. Wschr., 65, 1180. 